University of Nebraska - Lincoln

DigitalCommons@University of Nebraska - Lincoln

Publications from USDA-ARS / UNL Faculty

U.S. Department of Agriculture: Agricultural

Research Service, Lincoln, Nebraska

2014

Soil Greenhouse Gas Emissions in Response to Corn Stover

Removal and Tillage Management Across the US Corn Belt

Virginia L. Jin

USDA-ARS, virginia.jin@ars.usda.gov

John M. Baker

USDA-ARS, john.baker@ars.usda.gov

Jane M.F. Johnson

USDA-ARS, Jane.johnson@ars.usda.gov

Douglas Karlen

USDA-ARS, doug.karlen@ars.usda.gov

R. Michael Lehman

USDA-ARS, michael.lehman@ars.usda.gov

See next page for additional authors

Follow this and additional works at: https://digitalcommons.unl.edu/usdaarsfacpub

Jin, Virginia L.; Baker, John M.; Johnson, Jane M.F.; Karlen, Douglas; Lehman, R. Michael; Osborne, Shannon L.; Sauer, Thomas J.; Stott, Diane E.; Varvel, Gary E.; Venterea, Rodney T.; Schmer, Marty R.; and Wienhold, Brian J., "Soil Greenhouse Gas Emissions in Response to Corn Stover Removal and Tillage Management Across the US Corn Belt" (2014). Publications from USDA-ARS / UNL Faculty. 1639. https://digitalcommons.unl.edu/usdaarsfacpub/1639

This Article is brought to you for free and open access by the U.S. Department of Agriculture: Agricultural Research Service, Lincoln, Nebraska at DigitalCommons@University of Nebraska - Lincoln. It has been accepted for inclusion in Publications from USDA-ARS / UNL Faculty by an authorized administrator of DigitalCommons@University of Nebraska - Lincoln. 


\section{Authors}

Virginia L. Jin, John M. Baker, Jane M.F. Johnson, Douglas Karlen, R. Michael Lehman, Shannon L.

Osborne, Thomas J. Sauer, Diane E. Stott, Gary E. Varvel, Rodney T. Venterea, Marty R. Schmer, and Brian

J. Wienhold 


\title{
Soil Greenhouse Gas Emissions in Response to Corn Stover Removal and Tillage Management Across the US Corn Belt
}

\author{
Virginia L. Jin • John M. Baker • Jane M.-F. Johnson • Douglas L. Karlen • \\ R. Michael Lehman • Shannon L. Osborne - Thomas J. Sauer • Diane E. Stott • \\ Gary E. Varvel $\cdot$ Rodney T. Venterea • Marty R. Schmer • Brian J. Wienhold
}

Published online: 4 February 2014

(C) Springer Science+Business Media New York (outside the USA) 2014

This document is a U.S. government work and is not subject to copyright in the United States.

soil GHG emissions during the growing season varied widely across sites, by management, and by year. Overall, corn stover removal decreased soil total $\mathrm{CO}_{2}$ and $\mathrm{N}_{2} \mathrm{O}$ emissions by -4 and $-7 \%$, respectively, relative to no removal. No management treatments affected soil $\mathrm{CH}_{4}$ fluxes. When aggregated to total GHG emissions ( $\mathrm{Mg} \mathrm{CO}_{2}$ eq ha $\left.{ }^{-1}\right)$ across all sites and years, corn stover removal decreased growing season soil emissions by $-5 \pm 1 \%($ mean $\pm \mathrm{se})$ and ranged from $-36 \%$ to $54 \%(n=50)$. Lower GHG emissions in stover removal treatments were attributed to decreased $\mathrm{C}$ and $\mathrm{N}$ inputs into soils, as well as possible microclimatic differences associated with changes in soil cover. High levels of spatial and temporal variabilities in direct GHG emissions highlighted the importance of site-specific management and environmental conditions on the dynamics of GHG emissions from agricultural soils. nique as part of the USDA-ARS's Resilient Economic Agricultural Practices (REAP) regional partnership. Cumulative

V. L. Jin $(\bowtie) \cdot$ G. E. Varvel • M. R. Schmer • B. J. Wienhold USDA-Agricultural Research Service (ARS), 137 Keim Hall, University of Nebraska-Lincoln East Campus, Lincoln,

NE 68583-0937, USA

e-mail: Virginia.Jin@ars.usda.gov

J. M. Baker · R. T. Venterea

USDA-ARS, 1991 Upper Buford Circle, Saint Paul, MN 55108, USA

J. M.-F. Johnson

USDA-ARS, 803 Iowa Avenue, Morris, MN 56267, USA

D. L. Karlen · T. J. Sauer

USDA-ARS, 2110 University Boulevard, Ames, IA 50011, USA

R. M. Lehman · S. L. Osborne

USDA-ARS, 2923 Medary Avenue, Brookings, SD 57006, USA

D. E. Stott

USDA-ARS, 275 South Russell Street, West Lafayette, IN 47907 , USA
Keywords Corn stover · Tillage $\cdot$ Residue management . Static vented chamber $\cdot$ Carbon dioxide $\cdot$ Nitrous oxide . Methane

\section{Introduction}

The US Corn Belt is expected to be a major contributor of crop residues such as corn (Zea mays L.) stover for the nation's developing renewable biomass energy industry [26]. The sustainability of a corn stover-based bioenergy feedstock, however, will depend on identifying optimal stover harvest rates and site-specific management practices that maintain or improve soil organic carbon (SOC) levels, minimize the risks of soil erosion or loss in soil productivity, and reduce direct soil emissions of various greenhouse gases (GHGs) such as carbon dioxide $\left(\mathrm{CO}_{2}\right)$, nitrous oxide $\left(\mathrm{N}_{2} \mathrm{O}\right)$, and methane $\left(\mathrm{CH}_{4}\right)[5,6,21,24,26,30,61]$. 
A major challenge to determining optimal site-specific crop, soil, and residue management practices has been the paucity of field studies measuring the effects of stover removal on direct GHG emissions. Removal of corn stover is expected to decrease soil emissions of $\mathrm{CO}_{2}$ and other microbially derived GHGs by reducing the input of easily decomposable labile $C$ [13]. Results from the few empirical studies available addressing crop residue removal effects on soil GHG emissions, however, are inconsistent. In one study, corn stover removal did not alter soil $\mathrm{CO}_{2}$ or $\mathrm{N}_{2} \mathrm{O}$ emissions compared with stover retained treatments [25]. In other studies, removing crop residues decreased soil $\mathrm{N}_{2} \mathrm{O}$ emissions [13, 46], or residue retention stimulated $\mathrm{N}_{2} \mathrm{O}$ emission through new inputs of $\mathrm{N}$ in crop biomass $[3,18]$.

Alternative conservation tillage (ALT) practices (e.g., reduced tillage and no-tillage) are often recommended to ameliorate the potential negative effects of crop residue removal, which may include loss of soil organic carbon (SOC), increased soil compaction, disruption of soil aggregates, and reduced soil health $[4,16,17,32,58,59]$. Although the impacts of tillage on soil GHG emissions has been studied more widely than residue management, field studies also report contrasting results for tillage effects on soil $\mathrm{CO}_{2}$ and $\mathrm{N}_{2} \mathrm{O}$ emissions. Soil $\mathrm{CO}_{2}$ emissions under conservation tillage practices have been found to decrease $[1,2,43]$, increase $[3,40,56]$, or remain unchanged [13] compared with conventional tillage (CON). Similarly, soil $\mathrm{N}_{2} \mathrm{O}$ emissions under conservation tillage can also decrease $[13,42]$, increase $[3,35,53]$, or remain unchanged [15, 23, $39,48]$.

Because of the limited availability of measured soil $\mathrm{N}_{2} \mathrm{O}$ emissions under various residue and soil management practices, emissions are often estimated using the revised IPCC 1996 Tier 1 emission factor (EF) that approximates $\mathrm{N}_{2} \mathrm{O}-\mathrm{N}$ emissions as $1.25 \%$ of fertilizer $\mathrm{N}$ applied [20]. More recently, this value was revised downwards to $1.00 \%$ [9]. Whether and how stover removal or tillage impact emission factors can be discerned from spatial and temporal variabilities in landscape and weather, however, remains unclear as evidenced by the wide uncertainty range $(0.3-3 \%)$ reported for emission factors [9].

A primary goal for using coordinated, replicated field trials is to provide data to verify and improve modeled estimates of sustainable corn stover removal rates and the impacts of residue and soil management practices on direct soil GHG emissions. Currently, the USDA-Agricultural Research Service (ARS) is conducting a multi-location field assessment on the effects of corn stover removal and other management practices at nine maize production systems in five states (Indiana, Iowa, Minnesota, Nebraska, and South Dakota) across the US Corn Belt [50]. This research, which includes the quantification of direct GHG emissions, is part of the USDA-ARS's regional research partnership for Resilient
Economic Agricultural Practices (REAP, formerly the Renewable Energy Assessment Project; http://www.ars.usda.gov/ research $/$ programs $/$ programs.htm?np_code $=202 \&$ docid $=$ 15193) and a broad integrated study funded through USDA and DOE $[29,60]$. The objective of this report is to provide a regional summary of how corn stover removal under conventional tillage $(\mathrm{CON})$ or alternative conservation tillage (ALT) affects direct GHG emissions during the growing season in the US Corn Belt.

\section{Materials and Methods}

\section{Site Descriptions}

The nine study sites (Sites 1-9) used in this report span five states in the central USA (Table 1; Fig. 1). Three corn stover removal levels were tested, with all sites testing at least two levels: low residue removal (LRR), medium residue removal (MRR), or high residue removal (HRR). The LRR treatment consists of grain harvest only, with all stalks, leaves, and cobs remaining on the soil surface (equivalent to no removal of non-grain biomass). The MRR and HRR rates consist of differences in stalk cutting height $(30 \mathrm{vs} 10 \mathrm{~cm}$, respectively) or harvesting stover from half or all rows within a treatment for a uniform cutting height, respectively. Although stover removal methods and equipment vary from site to site, approximately $15-40 \%$ of the total stover produced is removed in MRR, and $>40 \%$ (up to $75 \%$ ) of the total stover biomass is removed in HRR at partnership sites measuring GHGs [29]. Other management practices (e.g., crop rotation; $\mathrm{N}$ fertilizer type and rate; irrigation; biochar application; and cover crops) and management timing vary by site, as appropriate to local soil and climate conditions (Table 2). Additional site-specific management records and environmental conditions are available online through the USDA-ARS REAP database (available at: http://nrrc.ars.usda.gov/reappb/\#/Home) and GRACEnet database (available at: http://nrrc.ars.usda.gov/slgracenet/ \#/Home) [11]. Although experimental designs and treatments vary by location depending on site-specific research questions, all sites evaluate at least two levels of corn residue removal. Results presented here are limited to comparing cumulative growing season GHG emissions in LRR and MRR and/or HRR treatments under conventional tillage (CON) practices ( $n=4$ sites) or alternative conservation tillage (ALT) practices ( $n=9$ sites). Specific tillage types for CON or ALT practices are defined by common producer practices at each location (Table 2). CON practices consisted of disk tillage at Site 6, chisel plow at Sites 2 and 5 , and moldboard plow at Site 3 . ALT practices consisted of strip tillage at Site 3 and no-tillage at all other sites. 
Table 1 Location and selected soil information $(0-15 \mathrm{~cm})$ for the Resilient Economic Agricultural Practices (REAP) regional partnership sites

\begin{tabular}{llllllllll}
\hline Site(s) & Location & $\begin{array}{l}\text { Latitude } \\
\left({ }^{\circ} \mathrm{N}\right)\end{array}$ & $\begin{array}{l}\text { Longitude } \\
\left({ }^{\circ} \mathrm{W}\right)\end{array}$ & $\begin{array}{l}\text { MAT } \\
\left({ }^{\circ} \mathrm{C}\right)\end{array}$ & $\begin{array}{l}\text { MAP } \\
(\mathrm{mm})\end{array}$ & $\begin{array}{l}\text { Texture } \\
\text { class/classes }\end{array}$ & $\begin{array}{l}\text { Soil pH } \\
(1: 1)\end{array}$ & $\begin{array}{l}\mathrm{SOM}^{\mathrm{b}} \\
\left(\mathrm{g} \mathrm{kg}^{-1}\right)\end{array}$ & $\begin{array}{l}\text { Dominant } \\
\text { soil series }^{2}\end{array}$ \\
\hline 1,2 & Morris, MN & 45.7 & 95.8 & 5.8 & 645 & $\mathrm{CL}$ & $6.0-6.3$ & $\sim 50$ & Barnes-Aastad \\
3 & Rosemount, MN & 44.3 & 96.8 & 6.4 & 879 & $\mathrm{SiL}$ & $5.8-6.0$ & $40-50$ & Waukegan \\
4 & Brookings, SD & 44.7 & 93.1 & 6.2 & 579 & $\mathrm{SiCL}$ & $6.3-7.3$ & $50+$ & Kranzburg-Brookings \\
5 & Ames, IA & 42.0 & 93.6 & 9.2 & 865 & $\mathrm{~L}, \mathrm{CL}, \mathrm{SiCL}$ & 6.5 & $30-50$ & Clarion-Nicollet-Webster \\
6 & Ithaca, NE & 41.2 & 96.5 & 10.5 & 766 & $\mathrm{SiL}$ & $7.6-7.7$ & $30-40$ & Tomek-Filbert \\
7 & Ithaca, NE & 41.2 & 96.5 & 10.5 & 766 & $\mathrm{SiL}$ & $5.2-6.9$ & $30-50$ & Tomek-Yutan \\
8 & Clay Center NE & 40.5 & 98.1 & 10.1 & 721 & $\mathrm{SiL}$ & $6.0-6.7$ & $30-40$ & Hastings \\
9 & West Lafayette, IN & 40.5 & 87.0 & 10.3 & 946 & $\mathrm{SiL}$ & 5.8 & $30-40$ & Octagon-Throckmorton
\end{tabular}

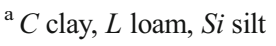

${ }^{\mathrm{b}} S O M$ soil organic matter

Gas Sampling and Analyses

Greenhouse gas emissions were measured and calculated at all sites using sampling designs and data processing protocols standardized by the USDA-ARS's Greenhouse Reduction through Agricultural Carbon Enhancement Network (GRACEnet) [19, 41]. Gas measurements were taken with static vented chambers using a stratified sampling design in which gases were sampled with syringes and injected into evacuated vials at three or four evenly spaced time-points over $30 \mathrm{~min}(0,15,30 \mathrm{~min}$; or 0, 10, 20, $30 \mathrm{~min})$. At Sites 1 and 2, sampling occurred at four time points within 30 min recording the time interval $[11,28]$. Minimum sample collection at all sites involved sampling every 7 to 14 days during the growing season; a subset of sites also measures GHGs monthly during the non-growing season. To account for diurnal variability, gas samples were usually collected between at times of the day closely corresponding to the daily average temperature (midmorning and early evening) [41].

At each site, three to six chamber replicates were measured per treatment combination. Concentrations of $\mathrm{CO}_{2}, \mathrm{~N}_{2} \mathrm{O}$, and/ or $\mathrm{CH}_{4}$ in air samples from the sampling chamber headspace

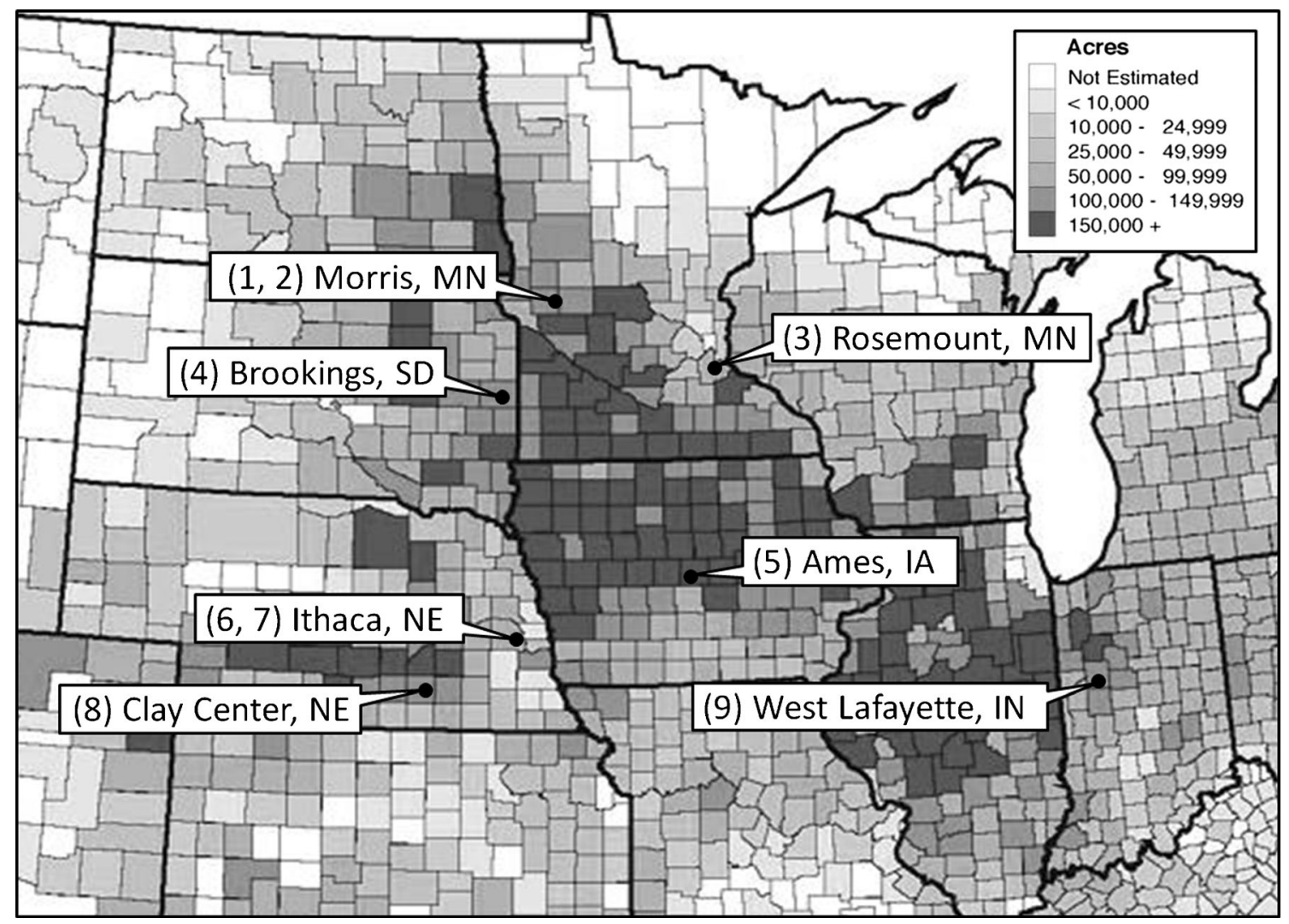

Fig. 1 Map of research site locations across the US Corn Belt. Shading indicates acreage in corn production by county [49] 
Table 2 Selected management information for the Resilient Economic Agricultural Practices (REAP) regional partnership sites

\begin{tabular}{|c|c|c|c|c|c|c|c|c|c|c|}
\hline Site & Location & Crop $^{a}$ & $\begin{array}{l}\mathrm{N} \\
\text { rate }^{\mathrm{b}}\end{array}$ & Tillage $^{c}$ & $\begin{array}{l}\text { Residue } \\
\text { removal }^{\mathrm{d}}\end{array}$ & $\begin{array}{l}\text { Tillage } \\
\text { start }^{\mathrm{e}}\end{array}$ & $\begin{array}{l}\mathrm{RR} \\
\text { start }^{\mathrm{f}}\end{array}$ & $\begin{array}{l}\text { Years } \\
\text { sampled }\end{array}$ & $\begin{array}{l}\text { Growing season } \\
\text { period sampled }^{\text {g }}\end{array}$ & Other $^{\mathrm{h}}$ \\
\hline 1 & Morris, MN & CS & 105 & ALT & LRR, HRR & 1995 & 2002 & $2008-2010$ & May 13-October 30 & NI \\
\hline 2 & Morris, MN & $\mathrm{CS}$ & 105 & ALT, CON & LRR, HRR & 2005 & 2005 & $2008-2010$ & May 13-October 30 & NI \\
\hline 3 & Rosemount, MN & $\mathrm{CC}$ & 146 & ALT, CON & LRR, MRR, HRR & 1991 & 2007 & 2010-2012 & May 22-September 15 & NI \\
\hline 4 & Brookings, SD & $\mathrm{CS}$ & 133 & ALT & LRR, MRR & 2000 & 2000 & 2008-2012 & May 26-September 20 & NI \\
\hline 5 & Ames, IA & $\mathrm{CC}$ & 224 & ALT, CON & LRR, MRR, HRR & 2007 & 2007 & 2010-2012 & April 19-October 2 & NI \\
\hline 6 & Ithaca, NE & $\mathrm{CC}$ & 202 & ALT, CON & LRR, HRR & 2001 & 2001 & 2011-2012 & April 19-September 18 & IR \\
\hline 7 & Ithaca, NE & $\mathrm{CC}$ & 120 & ALT & LRR, HRR & 1999 & 2000 & 2010-2012 & May 7-September 18 & NI \\
\hline 8 & Clay Center, NE & $\mathrm{CC}$ & 200 & ALT & LRR, HRR & 2010 & 2010 & 2011-2012 & May $1-$ September 25 & IR \\
\hline 9 & West Lafayette, IN & $\mathrm{CC}$ & 224 & ALT & LRR, MRR, HRR & 2004 & 2004 & 2008-2009 & May $1-$ October 1 & NI \\
\hline
\end{tabular}

${ }^{\mathrm{a}} \mathrm{CS}$ corn soybean rotation, $C C$ continuous corn

${ }^{\mathrm{b}} \mathrm{kg} \mathrm{N} \mathrm{ha}^{-1} \mathrm{y}^{-1}$; Site 5 (2010: 213, 238, $253 \mathrm{~kg} \mathrm{~N} \mathrm{ha}^{-1} \mathrm{y}^{-1}$ for LRR, MRR, HRR, respectively; 2011-2012: all $224 \mathrm{~kg} \mathrm{~N} \mathrm{ha}^{-1} \mathrm{y}^{-1}$ )

${ }^{\mathrm{c}} A L T$ conservation tillage (strip-till at Site 3, no-till at all other sites), $C O N$ conventional tillage (moldboard plow at Site 3; chisel plow at Sites 2, 5; disk tillage at Site 6)

${ }^{\mathrm{d}} L R R$ low residue removal, MRR medium residue removal, $H R R$ high residue removal

${ }^{\mathrm{e}}$ Year tillage treatments initiated; for Site 1, ALT treatment started in 1995 and CON started in 2002

${ }^{\mathrm{f}}$ Year residue removal treatments initiated

${ }^{\mathrm{g}}$ Average dates for sampling period during the growing season

${ }^{\mathrm{h}}$ IR irrigated, NI non-irrigated; for 2011 and 2012, respectively, Site 6 irrigated with 125,200 mm; Site 8 with 38,166 mm

were measured within 10 days of sample collection using a gas chromatograph equipped with a thermal conductivity detector $\left(\mathrm{CO}_{2}\right)$, electron capture detector $\left(\mathrm{N}_{2} \mathrm{O}\right)$, and flame ionization detector $\left(\mathrm{CH}_{4}\right)$. Soil gas emission rates were calculated as the change in headspace gas concentration over time within the enclosed chamber volume. Cumulative GHG emissions were estimated by linear interpolation of flux rates between sampling dates then summing daily rates over each growing season (i.e., trapezoidal integration method). Regional responses to corn residue removal and tillage practices are reported here as treatment means \pm standard errors across all sites.

Growing season dates and length varied across sites depending on geographic location and climate conditions. The growing season for each site was approximated as the period between corn planting and grain harvest (Table 2). For sites using corn-soybean (Glycine max (L.) Merr) rotations (Sites 1, 2 and 4), both crop phases were present each year of the study; only GHG measurements from the corn phase, however, were used in this survey to maintain consistency with measurements taken from continuous corn sites (Sites 3 and 5-9).

To account for site-specific management, the effect (\%) of corn stover removal (MRR and HRR) was calculated relative to no removal (LRR) at each location by tillage treatment for each growing season (Eq. 1)

$$
\frac{(M R R \text { or } H R R)-L R R}{L R R} * 100
$$

Positive values indicate that residue removal increased GHG emissions relative to no stover removal, and negative values indicate decreased emissions relative to no stover removal. Emission factors (EF, \%) for $\mathrm{N}_{2} \mathrm{O}-\mathrm{N}$ were also calculated to account for site-specific management during the growing season. For each site, an EF was calculated as the percent of $\mathrm{N}$ added as fertilizer which was lost as measured $\mathrm{N}_{2} \mathrm{O}-\mathrm{N}$ over the growing season. Background $\mathrm{N}_{2} \mathrm{O}$ emissions were not subtracted because such emissions in intensively managed soils are likely derived from fertilizer $\mathrm{N}$ or crop residues remaining from the previous season; thus, background emissions are included as an agriculturally derived component $[9,54]$. Values are reported as means \pm standard errors.

Weather data from the National Climate Data Center's Climate Data Online archive (http://www.ncdc.noaa.gov/ cdo-web/) or from on-site weather stations were used to calculate the average daily minimum and maximum air temperatures and the total precipitation received $(\mathrm{mm})$ during the growing season for each site and each year. For irrigated sites, irrigation amounts were added to precipitation received to account for the total water inputs each growing season.

\section{Statistical Analyses}

Each site reported mean growing season soil GHG emissions for multiple years (2008-2012), though not all sites reported data for all years or all tillage and residue removal treatment combinations (Table 2). A total of 87, 69, and 51 site-year 
observations were reported for mean cumulative growing season $\mathrm{CO}_{2}, \mathrm{~N}_{2} \mathrm{O}$, and $\mathrm{CH}_{4}$ emissions across all tillage and residue removal treatments $\left(\mathrm{kg} \mathrm{C}\right.$ or $\mathrm{N} \mathrm{ha}^{-1}$ growing season $^{-1}$ ), respectively. Total growing season GHG emissions was calculated as $\mathrm{CO}_{2}$-equivalents $\left(\mathrm{Mg} \mathrm{CO}_{2}\right.$ eq ha ${ }^{-1}$ growing season $^{-1}$ ) using 100-year global warming potentials for each GHG $\left(\mathrm{CO}_{2}=1, \mathrm{~N}_{2} \mathrm{O}=298\right.$, and $\left.\mathrm{CH}_{4}=25\right)$ [22].

Because not all stover removal-by-tillage treatments were represented at each site for all years (e.g., unbalanced experimental design), a generalized linear mixed effects analysis of variance (ANOVA) was used to assess the fixed effects of tillage (CON and ALT), residue removal (LRR, MRR and HRR), and their interaction on cumulative growing season $\mathrm{CO}_{2}, \mathrm{~N}_{2} \mathrm{O}, \mathrm{CH}_{4}$, and the total $\mathrm{GHG}$ emissions (PROC GLIMMIX; SAS v9.3; SAS, Inc., Cary, NC). Site, year, and their interaction were identified as random factors. Data were tested for normality using the Shapiro-Wilk statistic and transformed when necessary. For the limited data available from irrigated systems, the main and interaction effects of irrigation did not affect cumulative growing season GHG emissions (data not shown), so data were analyzed for tillage and stover removal effects only as described above. Posthoc multiple comparisons between fixed treatment means or differences from zero were tested using least squares means (LSMEANS).

Linear regressions for LRR and MRR+HRR (hereafter ' $R R$ ') were used to evaluate potential correlations between soil GHG emissions and (1) average minimum and maximum air temperatures during the growing season $\left({ }^{\circ} \mathrm{C}\right)$ and $(2)$ the total growing season precipitation received $(\mathrm{mm})$. Irrigation amounts at Sites 6 and 8 were included in growing season precipitation to represent the total water inputs in those systems. Similarly, correlations between $\mathrm{N}_{2} \mathrm{O}$ emission factors and air temperatures, growing season precipitation, and $\mathrm{N}$ fertilizer rate applied $\left(\mathrm{kg} \mathrm{N}^{-1} \mathrm{y}^{-1}\right)$ were also evaluated.

High variability in soil emissions due to geographic location and site-specific weather conditions decreases the statistical power to detect treatment effects. Thus, the probability of type I errors was countered against the increasing probability of type II errors (i.e., accepting the null hypothesis when false, or failing to declare a real difference as significant) by considering effects significant when $P \leq 0.10$ [62].

\section{Results}

Cumulative growing season soil GHG emissions varied widely across sites, by management, and by year. Across all sites, management, and years, mean cumulative growing season soil emissions were $3.4 \pm 0.2 \mathrm{Mg} \mathrm{CO}_{2}-\mathrm{C} \mathrm{ha}^{-1}(n=87), 1.6 \pm 0.1 \mathrm{~kg}$ $\mathrm{N}_{2} \mathrm{O}-\mathrm{N} \mathrm{ha}^{-1}(n=69)$, and $-0.12 \pm 0.04 \mathrm{~kg} \mathrm{CH}_{4}-\mathrm{C} \mathrm{ha}^{-1}(n=51)$ (Fig. $2 \mathrm{a}-\mathrm{c}$ ). For each $\mathrm{CO}_{2}$ and $\mathrm{N}_{2} \mathrm{O}$, growing season emissions contributed $76 \pm 1 \%(n=63)$ and $66 \pm 3 \%(n=45)$, respectively, to total annual emissions of each GHG (Mg C $\mathrm{ha}^{-1}$ or kg N ha ${ }^{-1}$, respectively) (Sites 1, 2, and 4-8). Growing season soil $\mathrm{CH}_{4}$ fluxes were highly variable and negligible in comparison with $\mathrm{CO}_{2}$ and $\mathrm{N}_{2} \mathrm{O}$ emissions; results and discussion focus on $\mathrm{CO}_{2}$ and $\mathrm{N}_{2} \mathrm{O}$ hereafter. Of the total $\mathrm{GHG}$ emitted during the growing season $\left(\mathrm{Mg} \mathrm{CO}_{2}\right.$ eq ha $\left.{ }^{-1}\right)$, soil emissions of $\mathrm{CO}_{2}$ contributed $93 \pm 1 \%$ and $\mathrm{N}_{2} \mathrm{O}$ contributed $7 \pm 1 \%$. The mean growing season total $\mathrm{GHG}$ emissions $\left(\mathrm{CO}_{2}\right.$, $\mathrm{N}_{2} \mathrm{O}, \mathrm{CH}_{4}$ ) was $12.9 \pm 0.7 \mathrm{Mg} \mathrm{CO}_{2}$ eq ha ${ }^{-1}$ for all sites, management, and years (Fig. 2d).

\section{Tillage Effects}

Cumulative growing season $\mathrm{CO}_{2}$ emissions were $12 \pm 4 \%$ higher in CON soils ( $\left.3.7 \pm 0.3 \mathrm{Mg} \mathrm{CO}_{2}-\mathrm{C} \mathrm{ha}^{-1}, n=28\right)$ relative to ALT soils $\left(3.2 \pm 0.2 \mathrm{Mg} \mathrm{CO}_{2}-\mathrm{C} \mathrm{ha}^{-1}, n=59\right)\left(P_{\text {tillage }}=\right.$ 0.0212; Sites 2, 3, 5, 6) (Fig. 2a). Although there was no main effect of tillage on soil $\mathrm{N}_{2} \mathrm{O}$ emissions $\left(\mathrm{kg} \mathrm{N}_{2} \mathrm{O}-\mathrm{N}\right.$ ha ${ }^{-1}$ ), cumulative growing season $\mathrm{N}_{2} \mathrm{O}$ emissions tended to be lower in CON than ALT (Fig. 2b). A marginal interaction between tillage and stover removal, however, showed that stover removal affected cumulative growing season $\mathrm{N}_{2} \mathrm{O}$ emitted in ALT soils only (see next section).

\section{Stover Removal Effects}

Cumulative growing season $\mathrm{CO}_{2}$ emissions $\left(\mathrm{Mg} \mathrm{CO}_{2}-\mathrm{C} \mathrm{ha}^{-1}\right)$ were $4 \pm 3 \%$ lower when corn stover was removed (MRR and HRR) compared with no removal (LRR) $\left(P_{\text {residue }}=0.0967\right.$; Table 3; Fig. 2a). Stover removal-by-tillage interaction was not significant for cumulative growing season $\mathrm{CO}_{2}$ emissions. In 2010 only, the effect (\% change) of residue removal (MRR and HRR) relative to no removal (LRR) treatments was lower than zero (i.e., zero $=$ no effect $)(\mathrm{CON}-17 \pm 6 \%$; ALT $-13 \pm$ $7 \%$; $P \leq 0.10$; Fig. 3a). In contrast during 2012, stover removal resulted in higher $\mathrm{CO}_{2}$ emissions from CON soils $(+26 \pm$ $15 \% ; P \leq 0.10$; Fig. 3a). Soil $\mathrm{CH}_{4}$ fluxes were not different from zero in LRR and MRR treatments, and HRR soils were minor $\mathrm{CH}_{4}$ sinks (Fig. 2c). Residue removal effects on the total $\mathrm{GHG}$ emissions $\left(\mathrm{Mg} \mathrm{CO} \mathrm{CO}_{2} \mathrm{eq}^{-1}\right.$ ) paralleled those observed for $\mathrm{CO}_{2}$ emissions (Fig. 2d, 3c).

Cumulative growing season $\mathrm{N}_{2} \mathrm{O}$ emissions $\left(\mathrm{kg} \mathrm{N}_{2} \mathrm{O}-\right.$ $\mathrm{N} \mathrm{ha}{ }^{-1}$ ) tended to be lower in ALT soils when stover was removed $\left(P_{\text {tillage* residue }}=0.1207\right)$ but had more variable effects in CON soils (Fig. 2b, 3b; Table 3). The average removal effect ( $\%$ change from LRR) in ALT soils was $-15 \pm 5 \%$ and was significantly lower than zero in 2009 and 2012 (Fig. 3b). In contrast, residue removal effects were significantly higher than zero for CON soils in 2011 and 2012 (Fig. 3b). In CON soils, the emission factor for growing season $\mathrm{N}_{2} \mathrm{O}$ emitted relative to $\mathrm{N}$ fertilizer applied ranged from 0.12 to $2.26 \%$ $(1.00 \pm 0.18 \%)$. For ALT soils, cumulative growing season $\mathrm{N}_{2} \mathrm{O}$ emissions with residue removal (MRR, HRR; $1.5 \pm$ 


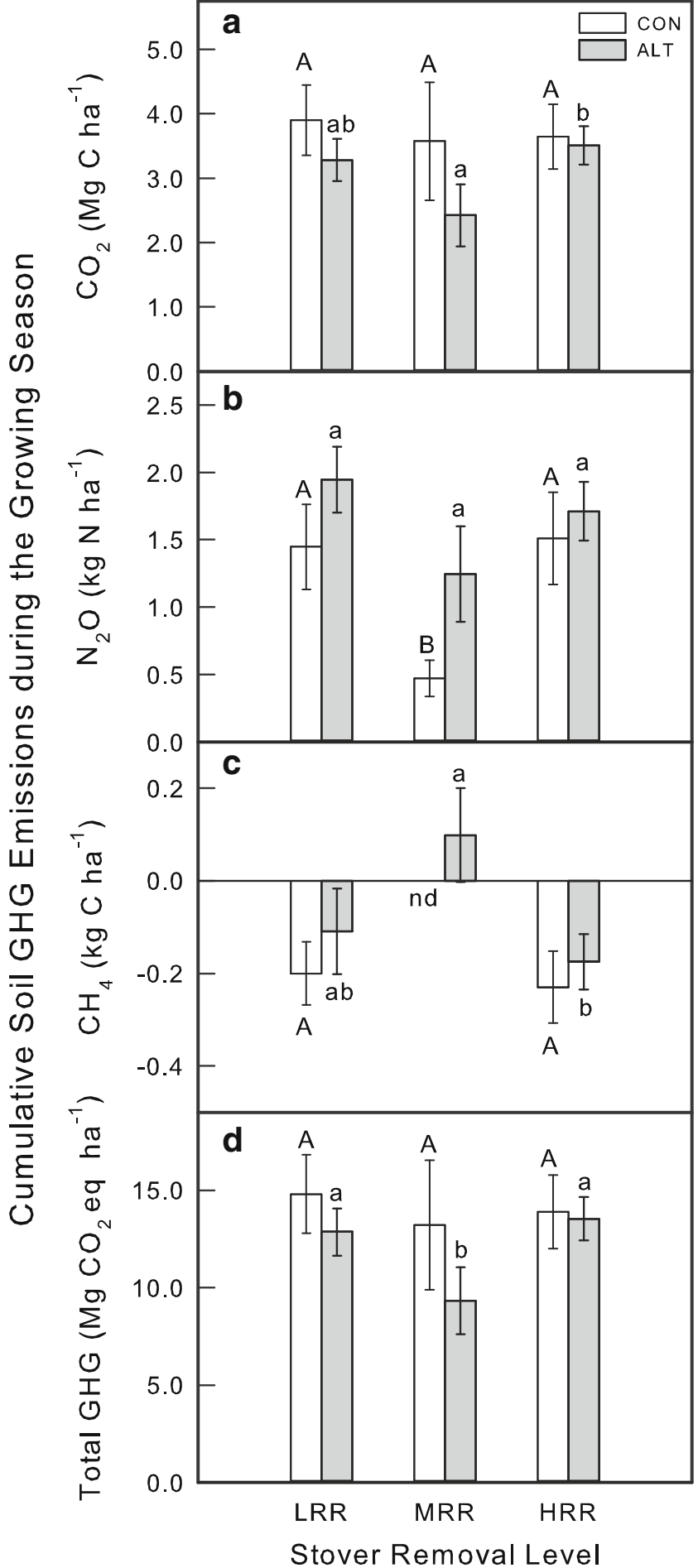

Fig. 2 Mean (se) cumulative soil emissions of (a) $\mathrm{CO}_{2}$, (b) $\mathrm{N}_{2} \mathrm{O}$, (c) $\mathrm{CH}_{4}$, and (d) the total GHGs during the growing season across all sites and years by tillage and residue management level. $C O N$ conventional tillage, $A L T$ alternative conservation tillage, $L R R$ low residue removal, $M R R$ medium residue removal $H R R$ high residue removal, $n d$ no data. Different upper case or lower case letters indicate significant differences between residue removal rates under conventional tillage and reduced/no tillage practices, respectively

$0.2 \mathrm{~kg} \mathrm{~N}_{2} \mathrm{O}-\mathrm{N}$ ha $^{-1}$ ) were lower relative to no removal (LRR; $1.9 \pm 0.2 \mathrm{~kg} \mathrm{~N}_{2} \mathrm{O}-\mathrm{N} \mathrm{ha}{ }^{-1}$ ). Emission factors for ALT soils with residue removal versus no removal were $1.10 \pm 0.15 \%$ and $1.39 \pm 0.18 \%$, respectively.

Correlations with Precipitation and Minimum Air Temperature

Cumulative growing season $\mathrm{CO}_{2}$ emissions were positively correlated to growing season precipitation received $(\mathrm{mm})$ and the sensitivity of $\mathrm{CO}_{2}$ emissions in response to precipitation (i.e., regression slope) was not affected by tillage or residue management (all data: $y=0.0048 x+1.4401, R^{2}=0.34$, $P<0.0001$ ) (Fig. 4). No correlations were found between cumulative growing season $\mathrm{CO}_{2}$ emissions and average daily minimum or maximum air temperatures over the growing season (data not shown).

Cumulative growing season $\mathrm{N}_{2} \mathrm{O}$ emissions also were positively correlated to growing season precipitation received (mm), which included irrigation amounts for Sites 6 and 8 (Fig. 5a). In ALT soils, residue removal ( $R R=M R R$ and HRR) decreased the sensitivity of this relationship as evidenced by a lower slope value compared with soils where no residue was removed (ALT: LRR, $y=0.005 \mathrm{x}-0.008, R^{2}=0.52, P=0.0001$; $\left.\mathrm{RR}, y=0.004 \mathrm{x}+0.13, R^{2}=0.40, P=0.0003\right)$. In contrast, cumulative growing season $\mathrm{N}_{2} \mathrm{O}$ emissions were negatively correlated with average daily minimum air temperature over the growing season, and the sensitivity of this relationship was not affected by residue removal (Fig. 5b) (ALT: LRR, $y=-$ $0.25 \mathrm{x}+5.29, R^{2}=0.19, P=0.05 ; \mathrm{RR}, y=-0.25 \mathrm{x}+5.00, R^{2}=$ $0.27, P=0.004)$.

The nitrogen emission factor $(\mathrm{EF})$ showed similar relationships with the total growing season precipitation received (Fig. 5c) (ALT: LRR, $y=0.003 \mathrm{x}+0.31, R^{2}=0.30, P=0.008$; $\left.\mathrm{RR}, y=0.002 \mathrm{x}+0.29, R^{2}=0.21, P=0.0144\right)$ and average daily minimum air temperature (Fig. 5d) (ALT: LRR, $y=-0.28 \mathrm{x}+$ 5.12, $R^{2}=0.43, P=0.0009 ; \mathrm{RR}, y=-0.25 \mathrm{x}+4.52, R^{2}=0.44, P=$ $0.0001)$. Emission factors were not correlated to annual $\mathrm{N}$ fertilizer rates across all sites, treatments, and years.

\section{Discussion}

For nine research sites spanning five states across the US Corn Belt, the magnitude of measured growing season GHGs emitted directly from soils $\left(12.9 \pm 0.7 \mathrm{Mg} \mathrm{CO}_{2} \mathrm{eq} \mathrm{ha}^{-1}\right)$ approximated those reported by other empirical or modeled studies in maize production systems $[8,24,25]$. Growing season soil GHG emissions were dominated by $\mathrm{CO}_{2}(>90 \%)$ with a small contribution from $\mathrm{N}_{2} \mathrm{O}(<10 \%)$. Soil $\mathrm{CH}_{4}$ production did not contribute significantly to the total GHG emissions; rather, soils were a slight sink for $\mathrm{CH}_{4}$ as has been noted in other agroecosystem studies [42, 57].

Overall, conventional tillage practices (CON) (i.e., disk tillage, chisel tillage, and moldboard plow) increased 
Table 3 Minimum ( $\min )$, maximum ( $\max$ ), and mean (standard error) residue removal effects on cumulative growing season $\mathrm{CO}_{2}, \mathrm{~N}_{2} \mathrm{O}$, and the total GHG emissions for medium and high residue removal rates (MRR and HRR) relative to no stover removal (LRR) by tillage treatment across all site years. Relative removal effect calculated as percent change from $\mathrm{LRR}=[(\mathrm{MRR}$ or $\mathrm{HRR})-\mathrm{LRR}] / \mathrm{LRR} \times 100 . C O N$ conventional tillage, $A L T$ reduced/no tillage

\begin{tabular}{|c|c|c|c|c|c|c|c|c|c|c|c|c|c|}
\hline \multirow[t]{2}{*}{ Tillage } & \multirow[t]{2}{*}{ Residue removal } & \multicolumn{4}{|c|}{$\begin{array}{l}\text { Relative removal effect } \\
\mathrm{CO}_{2}-\mathrm{C} \text { emitted }(\%)\end{array}$} & \multicolumn{4}{|c|}{$\begin{array}{l}\text { Relative removal effect } \\
\mathrm{N}_{2} \mathrm{O}-\mathrm{N} \text { emitted }(\%)\end{array}$} & \multicolumn{4}{|c|}{$\begin{array}{l}\text { Relative removal effect } \\
\text { Total } \mathrm{GHG} \mathrm{CO}_{2} \text { eq emitted (\%) }\end{array}$} \\
\hline & & $n$ & Min & Max & Mean & $n$ & Min & $\operatorname{Max}$ & Mean & $n$ & Min & Max & Mean \\
\hline \multirow[t]{2}{*}{$\mathrm{CON}$} & MRR & 6 & -30 & +68 & $+12(15)$ & 3 & -20 & +54 & $+25(23)$ & 6 & -30 & +54 & $+10(13)$ \\
\hline & HRR & 11 & -32 & +41 & $-5(5)$ & 8 & -58 & +35 & $+4(11)$ & 11 & -32 & +41 & $-5(5)$ \\
\hline \multirow[t]{2}{*}{ ALT } & MRR & 13 & -36 & +5 & $-9(6)$ & 10 & -56 & +34 & $-16(9)$ & 13 & -35 & +8 & $-9(4)$ \\
\hline & HRR & 20 & -36 & +27 & $-6(3)$ & 17 & -45 & +62 & $-14(6)$ & 20 & -33 & +25 & $-6(3)$ \\
\hline \multirow[t]{3}{*}{ All till } & MRR & 19 & -36 & +68 & $-2(6)$ & 13 & -56 & +54 & $-7(10)$ & 19 & -35 & +54 & $-3(5)$ \\
\hline & HRR & 31 & -36 & +41 & $-6(3)$ & 25 & -58 & +62 & $-8(5)$ & 31 & -33 & +41 & $-6(3)$ \\
\hline & All RR & 50 & -36 & +68 & $-4(3)$ & 38 & -58 & +62 & $-7(5)$ & 50 & -35 & +54 & $-4(3)$ \\
\hline
\end{tabular}

Fig. 3 Mean (se) effect of residue removal (MRR and HRR) relative to no stover removal (LRR) on cumulative growing season (a) $\mathrm{CO}_{2}$, (b) $\mathrm{N}_{2} \mathrm{O}$, and (c) the total GHG emissions by tillage treatment across all sites from 2008 to 2012. Relative removal effect calculated as percent change from LRR (relative removal effect $\%=[(\mathrm{MRR}$ or HRR) $-\mathrm{LRR}](\mathrm{LRR} \times 100) . C O N$ conventional tillage, $A L T$ alternative conservation tillage. Number of sites $(n)$ used for each mean calculation indicated. Asterisks indicate mean values significantly different from zero $(P \leq 0.10)$

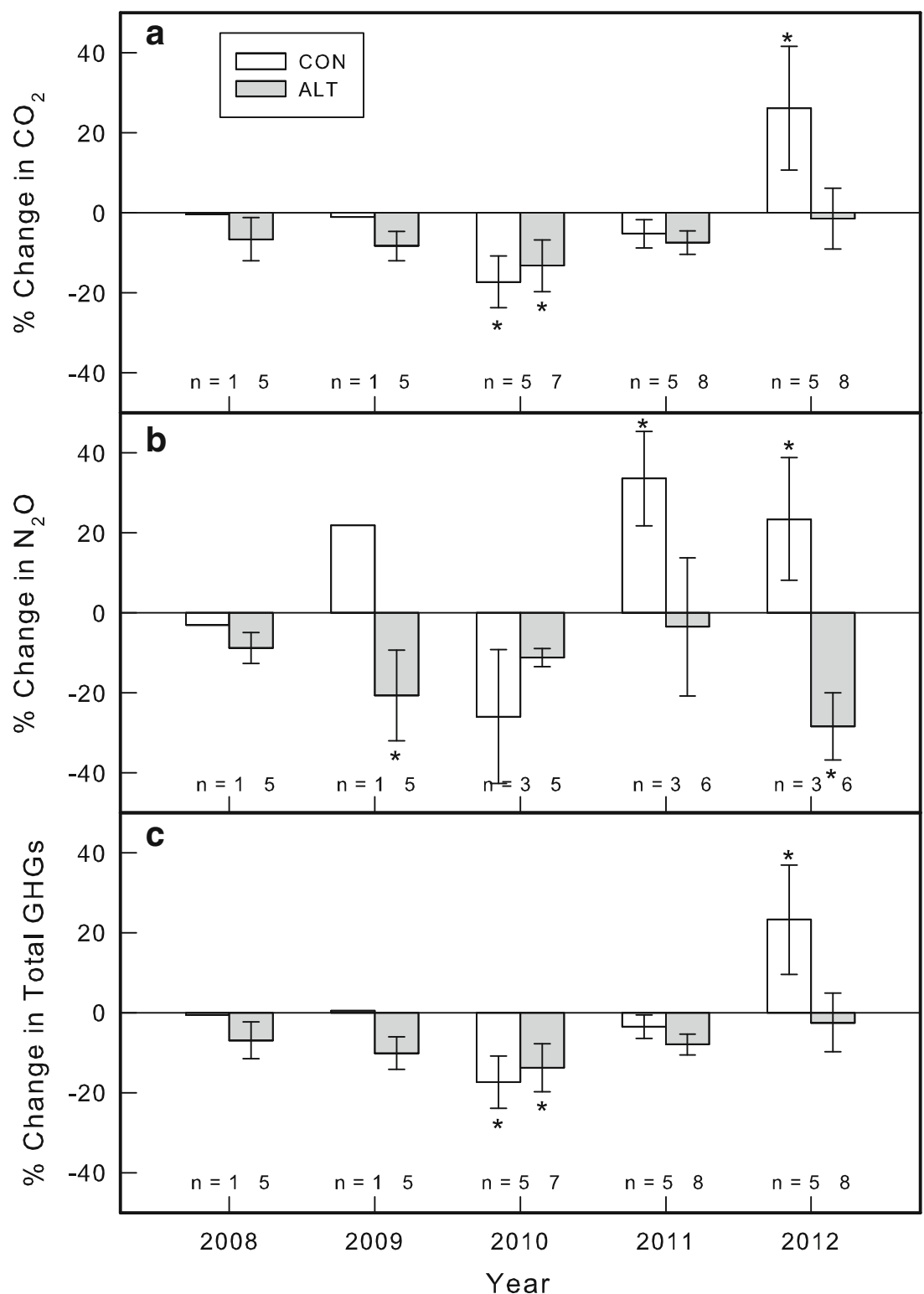




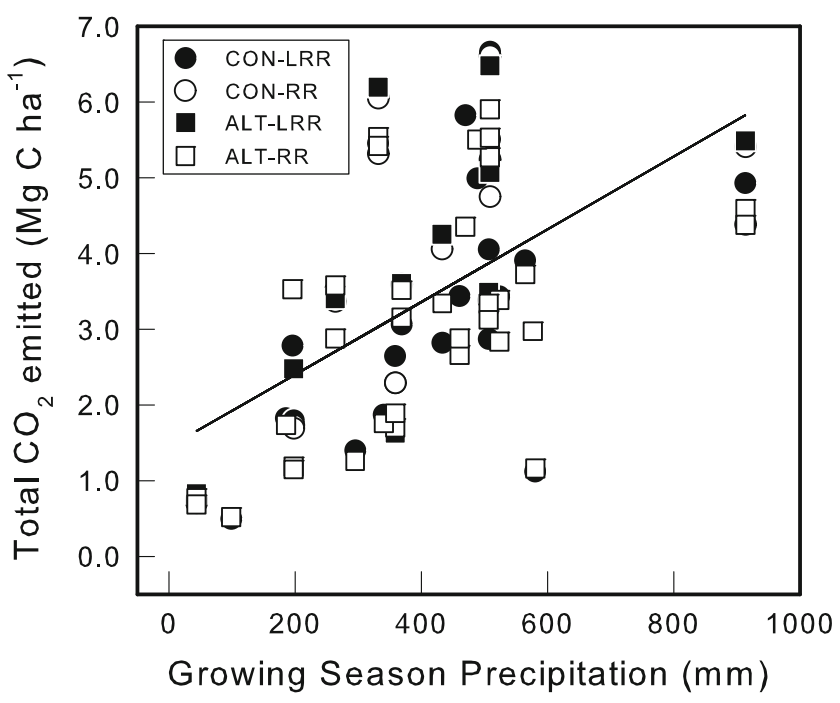

Fig. 4 Tillage and stover removal treatments did not affect the correlation between growing season cumulative soil $\mathrm{CO}_{2}$ emitted $\left(\mathrm{Mg} \mathrm{C} \mathrm{ha}{ }^{-1}\right)$ and growing season precipitation $(\mathrm{mm})$. Irrigation amounts were included in growing season precipitation values for Sites 6 and 8 to account for all water inputs. For all data, $y=0.0048 \mathrm{x}+1.4401, R^{2}=0.34, P<0.0001$

cumulative growing season soil $\mathrm{CO}_{2}$ emissions and tended to decrease soil $\mathrm{N}_{2} \mathrm{O}$ emissions compared with alternative conservation tillage management (ALT) (i.e., strip tillage and no

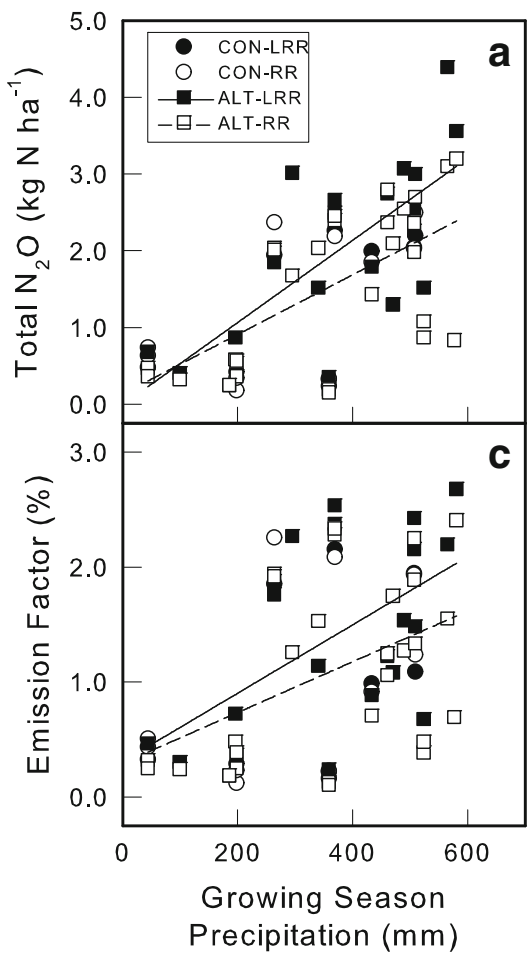

Fig. 5 Correlations between growing season cumulative soil $\mathrm{N}_{2} \mathrm{O}$ emissions and emission factors with environmental conditions, (a) the total growing season $\mathrm{N}_{2} \mathrm{O}-\mathrm{N}$ emitted versus the total growing season precipitation (ALT: LRR, $y=0.005 \mathrm{x}-0.008, R^{2}=0.52, P=0.0001$; RR, $y=$ $0.004 \mathrm{x}+0.13, R^{2}=0.40, P=0.0003$ ); (b) the total $\mathrm{N}_{2} \mathrm{O}-\mathrm{N}$ emitted versus the average daily minimum air temperature during the growing season (ALT: LRR, $y=-0.25 \mathrm{x}+5.29, R^{2}=0.19, P=0.05 ; \mathrm{RR}, y=-0.25 \mathrm{x}+5.00$, tillage). Conservation tillage is a key strategy for mitigating $\mathrm{CO}_{2}$ emissions from agriculture $[5,36]$ and has been shown to build soil organic carbon (SOC) in surface soils in the central US Corn Belt [27]. Net increases in SOC under no-till practices can also be accompanied by higher soil $\mathrm{CO}_{2}$ emissions due to greater microbial activity in surface layers [14, 34]. Accumulation of SOC and reduced soil disturbance in conservation tillage systems can also increase soil water content and create microsite conditions more favorable for denitrification $[34,47]$, a microbially mediated process that contributes significantly to agricultural soil $\mathrm{N}_{2} \mathrm{O}$ emissions [37]. Other factors including climate regime, duration of adoption, and $\mathrm{N}$ fertilizer placement can influence the effect of ALT practices on $\mathrm{N}_{2} \mathrm{O}$ emissions [55].

Removal of corn stover decreased plant $\mathrm{C}$ and $\mathrm{N}$ inputs into soils, limiting substrate availability of labile $\mathrm{C}$ and $\mathrm{N}$ sources for microbial use and decreased subsequent emissions of $\mathrm{CO}_{2}$ and $\mathrm{N}_{2} \mathrm{O}$. Moderate or high levels of corn stover removal (MRR and HRR) resulted in small but marginally significant decreases in the total growing season soil emissions of $\mathrm{CO}_{2}$ compared with the no stover removal treatment (LRR) when evaluated over all sites and all years. Stover removal also tended to interact with tillage such that only ALT soils showed a decrease in the total direct $\mathrm{N}_{2} \mathrm{O}$ emissions when stover was removed

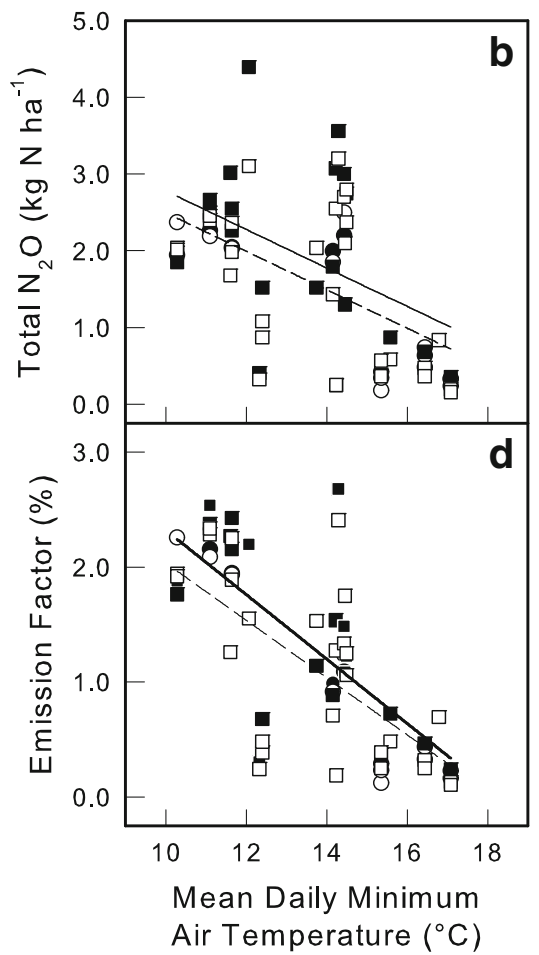

$\left.R^{2}=0.27, P=0.004\right)$; (c) emission factor versus the total growing season precipitation (ALT: LRR, $y=0.003 \mathrm{x}+0.31, R^{2}=0.30, P=0.008$; RR, $y=$ $\left.0.002 \mathrm{x}+0.29, R^{2}=0.21, P=0.0144\right)$; and (d) emission factor versus the average daily minimum air temperature during the growing season (ALT: LRR, $y=-0.28 \mathrm{x}+5.12, R^{2}=0.43, P=0.0009 ; \mathrm{RR}, y=-0.25 \mathrm{x}+4.52, R^{2}=$ $0.44, P=0.0001)$. Irrigation amounts were included in growing season precipitation values for Sites 6 and 8 to account for all water inputs 
compared with no removal. In other words, the effects of stover removal on the total growing season soil $\mathrm{N}_{2} \mathrm{O}$ emissions were diminished by the effect of conventional tillage. Retention of corn stover decreases evaporation and increases infiltration [4, $44,45]$, leading to higher soil water availability and soil stability $[1,33,61]$. As a result of greater resource availability (water, energy and nutrients), improvements in soil microsite conditions also likely contributed to greater GHG emissions from ALT soils when corn stover was retained.

Although the overall effect of stover removal was to decrease soil GHG emissions, inter-annual variability in regional weather affected whether relative residue removal effects ( $\%$ difference from LRR) were positive or negative for any given year. Expected negative residue removal effects on direct emissions of $\mathrm{CO}_{2}$, and to a lesser extent $\mathrm{N}_{2} \mathrm{O}$, in both tillage treatments were measured in 2010 . For conventionally tilled soils, significant positive effects of stover removal on soil $\mathrm{CO}_{2}$ in 2012 and $\mathrm{N}_{2} \mathrm{O}$ emissions in 2011-2012 appeared to reflect drier-than-normal conditions that began in 2011 and led into the prolonged extreme drought of 2012 that disproportionately affected the US Corn Belt [51].

The effect of environmental conditions on direct emissions of $\mathrm{CO}_{2}$ and $\mathrm{N}_{2} \mathrm{O}$ over the growing season was supported by observed relationships with precipitation inputs (which included irrigation amounts at Sites 6 and 8) and air temperature. Soil water availability and temperature have been found to be positively correlated with $\mathrm{CO}_{2}$ and $\mathrm{N}_{2} \mathrm{O}$ emissions from grain production systems $[2,13,38]$. In the current survey, direct emissions of both $\mathrm{CO}_{2}$ and $\mathrm{N}_{2} \mathrm{O}$ increased as the amount of the total growing season precipitation increased. No significant relationships, however, were observed between average daily maximum air temperature and the total $\mathrm{CO}_{2}$ or $\mathrm{N}_{2} \mathrm{O}$ emissions during the growing season across the nine sites included in this study. Instead, average daily minimum air temperature was negatively correlated with cumulative growing season $\mathrm{N}_{2} \mathrm{O}$ emissions. In contrast to the previously referenced studies, the observed negative temperature relationship appeared to correspond with the 2011-2012 drought that affected the US Corn Belt. Under the extreme drought conditions that developed, persistent high daytime air temperatures caused the average minimum daily temperature to also increase, resulting in the apparent negative temperature relationship for direct $\mathrm{N}_{2} \mathrm{O}$ emissions over the growing season. For both gases, the sensitivity of soil responses tended to be greater when corn stover was retained (i.e., higher values of regression slopes), again suggesting that resource availability and conditions in soils with residue cover enhanced microbial responses (both positive and negative) to environmental conditions.

Emission factors (EF) estimate direct $\mathrm{N}_{2} \mathrm{O}$ emissions as a percentage of fertilizer $\mathrm{N}$ applied [7, 9, 31], and at sufficiently large scales, modeled $\mathrm{N}_{2} \mathrm{O}$ emissions tend to converge with those estimated using the IPCC default EF value
$[10,12]$. For the nine sites in this regional survey, the absence of any correlation between $\mathrm{N}$ fertilization rate and emission factor (EF) across sites over the 5-year measurement period supports IPCC assumptions that applying an $\mathrm{EF}$ is a robust approach for estimating direct $\mathrm{N}_{2} \mathrm{O}$ emissions. Emission factors calculated in this study across all sites, years, and management approximated the $1.00 \% \mathrm{EF}$ in the 2006 IPCC guidelines [9]. When $\mathrm{N}$ fertilizer application rates exceed plant $\mathrm{N}$ demand, residual fertilizer $\mathrm{N}$ can lead to greater $\mathrm{N}_{2} \mathrm{O}$ emissions and results in an exponential relationship between $\mathrm{N}$ application rate and $\mathrm{N}_{2} \mathrm{O}$, emphasizing that other processes such as plant $\mathrm{N}$ uptake can significantly affect the direction, magnitude, and shape of this relationship [54]. In this study, results showing no relationship between $\mathrm{N}$ application rates and direct $\mathrm{N}_{2} \mathrm{O}$ emissions indicated that $\mathrm{N}$ was not applied in excess and that site-specific $\mathrm{N}$ management practices were appropriate. Negative correlations between EF and total growing season precipitation (including irrigation inputs) and mean daily minimum temperature suggest that environmental conditions will affect direct $\mathrm{N}_{2} \mathrm{O}$ emissions and shift $\mathrm{EF}$ values when $\mathrm{N}$ is applied at site-appropriate rates.

\section{Conclusion}

Agricultural management plays an important role in the mitigation of rising atmospheric greenhouse gas levels by promoting $\mathrm{C}$ sequestration in cropland soils and biomass and by potentially reducing GHG emissions. In this survey of nine sites across five states in the US Corn Belt, field measurements of cumulative growing season GHG emitted directly from soils demonstrated that (1) conventional tillage (CON) increased soil $\mathrm{CO}_{2}$ emissions and tended to decrease soil $\mathrm{N}_{2} \mathrm{O}$ emissions compared with alternative conservation tillage (ALT); (2) corn stover removal generally lead to reduced GHG emissions, particularly under ALT management; and (3) regionally scaled emission factors for direct emissions of $\mathrm{N}_{2} \mathrm{O}$ over the growing season as a percentage of $\mathrm{N}$ fertilizer applied could be predicted by environmental conditions such as the total growing season precipitation and annual daily minimum temperature. The use of ALT practices when corn stover is removed can ameliorate potential soil erosion issues as well as decrease direct GHG emissions. Initial estimates indicate that removing $30 \%$ of stover produced in intensive no-till corn production areas in the US Corn Belt could adequately support annual bioenergy feedstock demand of $\sim 100$ million $\mathrm{Mg}$ of stover [17]. Updated estimates suggest that stover removal rates could vary from 15 to $50 \%$ under ALT practices [52]. Optimal stover removal rates, however, will depend on site specific management decisions and environmental conditions and is the subject of an ongoing research. 
Acknowledgments Funding for this project was provide by the United States Department of Agriculture-Agricultural Research Service (USDAARS), as part of the USDA-ARS-Renewable Energy Assessment Project (REAP), renamed USDA-ARS-Resilient Economic Agricultural Practices (REAP). Additional funding was from the North Central Regional SunGrant Center at South Dakota State University through a grant provided by the United States Department of Energy - Office of Biomass Programs under award number DE-FC36-05GO85041. Technical assistance in the field and/or laboratory is acknowledged from Kayla Miller, Meggan Kowalski, Kurt Dagel, Amy Christie, Sharon Nichols, Don Watts, Joe Million, Jerry Martin, Ray Winans, Anthony Shriner, Warren Busscher, Carla Ahlschwede, Chris Bauer, Aaron Bereuter, Todd Boman, Robert Harrington, Molly Hoffbauer, Angel Iverson, Tanner Lockhorn, Paul Koerner, Nate Mellor, Dan Miller, Sara Murray, Marty Schmer, Susan Siragusa-Ortman, Steve Swanson, Tyler Goeschel, David Walla, Kevin Jensen, Dawn Schroeder, Gary Radke, Tim Parkin, Amy Morrow, and Bryan Woodbury. Special thanks to Nancy Barbour, Jon Starr, and Greg Wilson for the assistance with the REAP database. The use of trade, firm, or corporation names in this publication is for the information and convenience of the reader. Such use does not constitute an official endorsement or approval by the United States Department of Agriculture or the Agricultural Research Service of any product or service to the exclusion of others that may be suitable. The USDA is an equal opportunity provider and employer.

\section{References}

1. Alluvione F, Halvorson AD, Del Grosso SJ (2009) Nitrogen, tillage, and crop rotation effects on carbon dioxide and methane fluxes from irrigated cropping systems. J Environ Qual 38:2023-2033

2. Almaraz JJ, Zhou XM, Mabood F, Madramootoo C, Rochette P, Ma BL, Smith DL (2009) Greenhouse gas fluxes associated with soybean production under two tillage systems in southwestern Quebec. Soil Till Res 104:134-139

3. Baggs EM, Stevenson M, Pihlatie M, Regar A, Cook H, Cadisch G (2003) Nitrous oxide emissions following application of residues and fertilizer under zero and conventional tillage. Biol Fert Soils 254: 361-370

4. Blanco-Canqui H, Lal R (2007) Soil and crop response to harvesting corn residues for biofuel production. Geoderma 141:355-362

5. Cambardella CA, Johnson JM-F, Varvel GE (2012) Soil carbon sequestration in central US agroecosystems. In: Liebig MA, Franzleubbers AJ, Follett RF (eds) Managing agricultural greenhouse gases: coordinated agricultural research through GRACEnet to address our changing climate. Academic Press, San Diego, pp 41-58

6. Cavigelli MA, Parkin TB (2012) Cropland management contributions to GHG flux: central and eastern USA. In: Liebig MA, Franzleubbers AJ, Follett RF (eds) Managing agricultural greenhouse gases: coordinated agricultural research through GRACEnet to address our changing climate. Academic Press, San Diego, pp 177-234

7. Crutzen PJ, Mosier AR, Smith KA, Winiwarter W (2008) $\mathrm{N}_{2} \mathrm{O}$ release from agro-biofuel production negates global warming reduction by replacing fossil fuels. Atmos Chem Phys 8:389-395

8. Davis SC, Parton WJ, Del Grosso SJ, Keough C, Marx E, Adler PR, DeLucia EH (2012) Impact of second generation biofuel agriculture on greenhouse gas emissions in the corn growing regions of the USA. Front Ecol Environ 10:69-74

9. de Klein C, Novoa RSA, Ogle S, Smith KA, Rochette P, Wirth TC, McConkey BG, Mosier AR, Rypdal K, Walsh M, Williams SA (2006) $\mathrm{N}_{2} \mathrm{O}$ emissions from managed soils and $\mathrm{CO}_{2}$ emissions from lime and urea application. In: Eggleston S, Buendia L, Miwa K, Ngara T, Tanabe K (eds) IPCC guidelines for national greenhouse gas inventories. Institute for Global Environmental Strategies, Japan, pp 11.1-11.54

10. Del Grosso SJ, Parton WJ, Mosier AR, Walsh MK, Ojima DS, Thornton PE (2006) DAYCENT national-scale simulations of nitrous oxide emissions from cropped soils in the United States. J Environ Qual 35:1451-1460

11. Del Grosso SJ, White JW, Wilson G, Vandenberg BC, Karlen DL, Follett RF, Johnson JM-F, Franzluebbers AJ, Archer DW, Gollany HT, Liebig MA, Ascough JC II, Reyes-Fox MA, Starr JL, Barbour NW, Polumsky RW, Gutwein M, James DE, Pellack LS (2013) Introducing the GRACEnet/REAP data contribution, discovery and retrieval system. J Env Qual 42:1274-1280

12. Del Grosso SJ, Wirt T, Ogle SM, Parton WJ (2008) Estimating agricultural nitrous oxide emissions. Eos, Trans Amer Geophys Union 89:529-530

13. Dendooven L, Patino-Zuniga L, Verhulst N, Luna-Guido M, Marsch R, Govaerts B (2012) Global warming potential of agricultural systems with contrasting tillage and residue management in the central highlands of Mexico. Agric Ecosys Environ 152:50-58

14. Doran JW (1980) Microbial changes associated with residue management and reduced tillage. Soil Sci Soc Am J 44:518-524

15. Elmi AA, Madramootoo C, Hamel C, Liu A (2003) Denitrification and nitrous oxide to nitrous oxide plus dinitrogen ratios in the soil profile under three tillage systems. Biol Fertil Soils 38:340-348

16. Follett RF (2001) Soil management concepts and carbon sequestration in cropland soils. Soil Till Res 61:77-92

17. Graham RL, Nelson R, Sheehan J, Perlack RD, Wright LL (2007) Current and potential US corn stover supplies. Agron J 99:1-11

18. Harrison R, Ellis S, Cross R, Hodgson JH (2002) Emissions of nitrous oxide and nitric oxide associated with the decomposition of arable crop residues on a sandy loam soil in Eastern England. Agronomie (France) 22:731-738

19. Hutchinson GL, Mosier AR (1981) Improved soil cover method for field measurement of nitrous oxide fluxes. Soil Sci Soc Am J 43:311316

20. IPCC (1997) Intergovernmental panel on climate change. In: Houghton JT (ed) Revised 1996 IPCC guidelines for national greenhouse gas inventories: volumes 1, 2 and 3. IPCC/OECD/IEA, Paris

21. IPCC (2007) Fourth assessment report of the intergovernmental panel on climate change. In: Metz B, Davidson OR, Bosch PR, Dave R, Meyer LA (eds) Working group III: mitigation of climate change. Cambridge University Press, Cambridge

22. IPCC (2007) Fourth assessment report of the intergovernmental panel on climate change. In: Solomon S, Qin D, Manning M, Chen Z, Marquis M, Averyt KB, Tignor M, Miller HL (eds) Working group I: the physical science basis. Cambridge University Press, Cambridge

23. Jantalia CP, dos Santos HP, Urquiaga S, Boddey RM, Alves BJR (2008) Fluxes of nitrous oxide from soil under different crop rotations and tillage systems in the South of Brazil. Nutr Cycl Agroecosyst 82: $161-173$

24. Johnson JM-F, Archer DW, Barbour NW (2010) Greenhouse gas emission from contrasting management scenarios in the Northern Corn Belt. Soil Sci Soc Am J 74:396-401

25. Johnson JM-F, Barbour NW (2010) Crop yield and greenhouse gas response to stover harvest on glacial till Mollisol. Proceedings from the 19th World Congress of, Soil Science, pp 36-39

26. Johnson JM-F, Coleman MD, Gesch RW, Jaradat AA, Mitchell R, Reicosky DC et al (2007) Biomass-bioenergy crops in the United States: a changing paradigm. Americas J Plant Sci Biotech 1:1-28

27. Johnson JM-F, Reicosky DC, Allmaras RR, Sauer TJ, Venterea RT, Dell CJ (2005) Greenhouse gas contributions and mitigation potential of agriculture in the central USA. Soil Till Res 83:73-94

28. Johnson JMF, Weyers SL, Archer DW, Barbour NW (2012) Nitrous oxide, methane emission, and yield-scaled emission from organically and conventionally managed systems. Soil Sci Soc Am J 76:13471357 
29. Karlen DL (2010) Corn stover feedstock trials to support predictive modeling. Glob Chang Biol Bioenergy 2:235-247

30. Karlen DL, Varvel GE, Johnson JM-F, Baker JM, Osborne SL, Novak JM, Adler PR, Roth GW, Birrell SJ (2011) Monitoring soil quality to assess the sustainability of harvesting corn stover. Agron J 103:288-295

31. Kim S, Dale BE (2008) Effects of nitrogen fertilizer application on greenhouse gas emissions and economics of corn production. Environ Sci Technol 42:6028-6033

32. Lal R, Kimble JM (1997) Conservation tillage for carbon sequestration. Nutr Cycling Agroecosyst 49:243-253

33. Lichter K, Govaerts B, Six J, Sayre KD, Deckers J, Dendooven L (2008) Aggregation and $\mathrm{C}$ and $\mathrm{N}$ contents of soil organic matter fractions in the permanent raised bed planting system in the highlands of Central Mexico. Plant Soil 305:237-252

34. Linn DM, Doran JW (1984) Aerobic and anaerobic microbial populations in no till and plowed soils. Soil Sci Soc Am J 48: 794-799

35. Millar N, Ndufa JK, Cadisch G, Baggs EM (2004) Nitrous oxide emissions following incorporation of improved fallow residues in the humid tropics. Glob Biogeochem Cycles 18: GB1032 doi:10.1029/ 2003GB002114

36. Morgan JA, Follett RF, Allen LH Jr, Del Grosso S, Derner JD, Dijkstra F, Franzleubbers A, Fry R, Paustian K, Schoeneberger MM (2010) Carbon sequestration in agricultural lands of the United States. J Soil Water Conserv 65:6A-13A

37. Mosier AR, Duxbury JM, Freney JR, Heinemeyer O, Minami K (1996) Nitrous oxide emissions from agricultural fields: assessment measurement and mitigation. Plant Soil 181:95-108

38. Novoa RSA, Tejeda HR (2006) Evaluation of the $\mathrm{N}_{2} \mathrm{O}$ emissions from $\mathrm{N}$ in plant residues as affected by environmental and management factors. Nutr Cycl Agroecosyst 75:29-46

39. Omonode RA, Vyn TJ, Smith DR, Hegymegi P, Gal A (2007) Soil carbon dioxide and methane fluxes from long term tillage systems in continuous corn and corn-soybean rotations. Soil Till Res 95:182195

40. Oorts K, Merckx R, Grehan E, Labreuche J, Nicolardot B (2007) Determinants of annual fluxes of $\mathrm{CO}_{2}$ and $\mathrm{N}_{2} \mathrm{O}$ in long term no tillage and conventional tillage systems in northern France. Soil Till Res 95: 133-148

41. Parkin TB, Venterea RT (2010) Sampling Protocols. Chapter 3. Chamber-based trace gas flux measurements. In: Sampling Protocols. Follett RF (ed) pp 3-1 to 3-39. http://www.ars.usda.gov/ research/GRACEnet Chamber Based Trace Gas Flux Measurements. Accessed 1 February 2011

42. Robertson GP, Paul EA, Harwood RR (2000) Greenhouse gases in intensive agriculture: contributions of individual gases to the radiative forcing of the atmosphere. Science 289: 1922-1925

43. Sainju UM, Jabro JD, Stevens WB (2008) Soil carbon dioxide emission and carbon content as affected by irrigation tillage cropping system and nitrogen fertilization. J Environ Qual 36: 97-107

44. Sauer TJ, Hatfield JL, Prueger JH, Norman JM (1998) Surface energy balance of a corn residue covered field. Agr Forest Meteorol 89:155168

45. Shaver TM, Peterson GA, Ahuja LR, Westfall DG, Sherrod LA, Dunn G (2002) Surface soil properties after twelve years of dryland no-till management. Soil Sci Soc Am J 66:1292-1303
46. Singh B, Shan YH, Johnson-Beebout SE, Singh Y, Buresh RJ (2008) Crop residue management for lowland rice based cropping systems in Asia. Adv Agron 98:117-199

47. Six J, Ogle SM, Breidt FJ, Conant RT, Mosier AR, Paustian K (2004) The potential to mitigate global warming with no-tillage management is only realized when practised in the long term. Global Change Biol $10: 155-160$

48. Smith DR, Hernandez-Ramirez G, Armstrong SD, Bucholtz DL, Stott DE (2011) Fertilizer and tillage management impacts on noncarbon dioxide greenhouse gas emissions. Soil Sci Soc Am J 75: 1070-1082

49. U.S. Department of Agriculture - National Agricultural Statistics Service (2010) Production average of corn by county in the United States. http://www.nass.usda.gov/Charts_and_Maps/Crops_County/ index.asp Accessed 20 August 2011

50. U.S. Department of Agriculture-Agricultural Research Service (2010) Impact of residue removal for biofuel production on soil: Renewable Energy Assessment Project (REAP). http://www.ars. usda.gov/research/programs/programs.htm?np_code $=212 \&$ docid $=$ 21224. Accessed 14 August 2013

51. U.S. Department of Agriculture-Economic Research Service (2013) U.S. drought 2012: farm and food impacts. http://www.ers.usda.gov/ topics/in-the-news/us-drought-2012-farm-and-food-impacts.aspx. Accessed 27 Jan 2014

52. U.S. Department of Energy (2011) U.S. billion-ton update: biomass supply for a bioenergy and bioproducts industry. In: Perlack RD, Stokes BJ (eds) ORNL/TM-2011/224. Oak Ridge National Laboratory, Oak Ridge

53. Ussiri DAN, Lal R (2009) Long-term tillage effects on soil carbon storage and carbon dioxide emissions in continuous corn cropping system from an Alfisol in Ohio. Soil Till Res 104:39-47

54. Van Groenigen JW, Velthof GL, Oenema O, Van Groenigen KJ, Van Kessel C (2010) Towards an agronomic assessment of $\mathrm{N}_{2} \mathrm{O}$ emissions: a case study for arable crops. Eur J Soil Sci 61:903-913

55. Van Kessel C, Venterea R, Six J, Adviento BA, Linquist B, Van Groeningen KJ (2013) Climate and N placement determine $\mathrm{N}_{2} \mathrm{O}$ emissions in reduced tillage systems. Global Change Biol 19:33-44

56. Venterea RT, Baker JM, Dolan MS, Spokas KA (2006) Soil carbon and nitrogen storage are greater under biennial tillage in a Minnesota corn-soybean rotation. Soil Sci Soc Am J 70:1752-1762

57. Venterea RT, Burger M, Spokas KA (2005) Nitrogen oxide and methane emissions under varying tillage and fertilizer management. J Environ Qual 34:1467-1477

58. West TO, Post WM (2002) Soil organic carbon sequestration rates by tillage and crop rotation: a global data analysis. Soil Sci Soc Am J 66: 1930-1946

59. Wienhold BJ, Varvel GE, Johnson JMF, Wilhelm WW (2013) Carbon source quality and placement effects on soil organic carbon status. Bioenergy Res 6:786-796

60. Wilhelm WW, Hess JR, Karlen DL, Johnson JMF, Muth DJ, Baker JM, Gollany HT, Novak JM, Stott DE, Varvel GE (2010) Review: balancing limiting factors \& economic drivers for sustainable Midwestern US agricultural residue feedstock supplies. Industrial Biotechnol 6:271-287

61. Wilhelm WW, Johnson JM-F, Karlen DL, Lightle DT (2007) Corn stover to sustain soil organic carbon further constrains biomass supply. Agron J 99:1665-1667

62. Zar JH (1996) Biostatistical analysis, 3rd edn. Prentice Hall, Upper Saddle River 